\title{
Debaryomyces prosopidis sp. nov., a yeast from exudates of mesquite trees
}

\author{
Herman J. Phaff, ${ }^{1}$ Ann Vaughan-Martini ${ }^{2}$ and William T. Starmer ${ }^{3}$ \\ Author for correspondence: Herman J. Phaff. Tel: +1530752 1465. Fax: +15307524759. \\ e-mail: hjphaff $a$ ucdavis.edu
}

\footnotetext{
1 Department of Food Science and Technology, University of California, Davis, CA 95616, USA

2 Dipartimento di Biologia Vegetale, Università degli Studi, Perugia, Italy 06121

3 Department of Biology, Syracuse University, Syracuse, NY 13244, USA
}

\begin{abstract}
Nine strains were studied of a new haploid species of the genus Debaryomyces Lodder \& Kreger-van Rij that had been isolated from exudates of mesquite (Prosopis juliflora) trees in southern Arizona and from Drosophila carbonaria that breeds in these exudates. Their physiological characteristics, life cycle, and nuclear DNA base composition (approx. $37.5 \mathrm{~mol} \% \mathrm{G}+\mathrm{C}$ ) led to their original classification as Debaryomyces hansenii (Zopf) Kreger-van Rij. However, the two taxa are, at most, distantly related based on DNA reassociation values that indicated low base sequence complementarity. The two taxa also have distinctly different electrophoretic karyotypes. Debaryomyces hansenii has two varieties, $D$. hansenii var. hansenii and D. hansenii var. fabryi. Debaryomyces prosopidis can be differentiated phenotypically from both varieties by lack of growth on cellobiose after 2 weeks incubation and from the variety hansenii by a higher maximum temperature for growth. The type strain of Debaryomyces prosopidis sp. nov. is strain UCD-FST 84-100' (= DBVPG 7010' $=$ CBS 8450 $^{\top}=$ ATCC 201611 $^{\top}$ ).
\end{abstract}

Keywords: Prosopis juliflora (mesquite), Debaryomyces prosopidis sp. nov.

\section{INTRODUCTION}

Yeasts associated with decaying cactus tissue in the Americas and with Drosophila species breeding in these necroses have been studied extensively since the early seventies (Starmer et al., 1990). These studies have shown that the great majority of yeast species occurring in this habitat are cactus specific and therefore not found in other plant tissues that support the growth of yeasts (Phaff \& Starmer, 1987). Because some yeast species occur in cactus necroses as well as in other plant habitats, Ganter et al. (1986) investigated the yeast communities in a relatively narrow geographic area near Tucson, Arizona, USA. They compared the yeast community compositions in necrotic Carnegica gigantea (saguaro) and in several Opuntia species with those found in exudates (slime fluxes) of several species of trees in the same area.

Among the yeast isolates that occurred only in tree exudates and not in cactus necroses were 30 strains identified as Debaryomyces hansenii that came from exudates of mesquite trees (Prosopis juliflora). An additional three strains were isolated from Drosophila carbonaria that breeds in exudates from mesquite trees.

The present study reports the results of a reinvestigation of nine representative strains of these yeast isolates by molecular techniques. The results showed that these strains represent a new species of the genus Debaryomyces which is described here as Debaryomyces prosopidis $\mathrm{sp}$. nov.

\section{METHODS}

Isolation and identification of organisms. Strains studied are listed in Table 1. Where possible, information is provided regarding the isolation source and location, other collection numbers, and original species designations if different from the present epithet. Cultures associated with Prosopis juliflora Amargo (mesquite) were collected in 1975 and 1984 from fluxes or from Drosophila carbonaria Patterson and Wheeler associated with the plant exudates.

All strains were compared phenotypically by standard methods as described by van der Walt \& Yarrow (1984). Growth responses were determined in liquid medium on a roller drum at $25^{\circ} \mathrm{C}$. Maximum growth temperature was tested at one-degree intervals in tubes containing YEPG $[1 \%(\mathrm{w} / \mathrm{v})$ yeast extract, $1 \%(\mathrm{w} / \mathrm{v})$ peptone, $2 \%(\mathrm{w} / \mathrm{v})$ glucose] in a constant-temperature water bath with gentle shaking at 125 r.p.m. Ability to assimilate additional carbon compounds including hexadecane, methanol, D-glucosamine, $N$-acetyl-D-glucosamine, 2-propanol, acetone and ethyl acetate was also tested. The last three compounds, as well as hexadecane were tested as described by Phaff et al. (1997) 
Table 1. Strains studied

\begin{tabular}{|c|c|}
\hline Species/strain designation* & Original designation/isolation information/source \\
\hline \multicolumn{2}{|l|}{ Debaryomyces castellii Capriotti } \\
\hline DBVPG $7068^{\mathrm{T}}$, UCD $69-35^{\mathrm{T}}$ & Soil, Sweden \\
\hline \multicolumn{2}{|l|}{ Debaryomyces coudertii } \\
\hline DBVPG $7124^{\mathrm{T}}$, UCD $69-36^{\mathrm{T}}$ & Faeces of Emperor penguin \\
\hline \multicolumn{2}{|c|}{ Debaryomyces hansenii (Zopf) Lodder \& Kreger-van Rij-like } \\
\hline DBVPG $7010^{\mathrm{T}}$, UCD $84-100^{\mathrm{T}}$ & Prosopis juliflora Amargo (mesquite) flux, Arizona, USA \\
\hline DBVPG 7011, UCD 84-101 & Prosopis juliflora Amargo (mesquite) flux, Arizona, USA \\
\hline DBVPG 7012, UCD 84-102 & $\begin{array}{l}\text { Drosophila carbonaria Patterson and Wheeler near Prosopis juliflora } \\
\text { Amargo (mesquite) flux, Arizona, USA }\end{array}$ \\
\hline DBVPG 7109, UCD 76-11 & Prosopis juliflora Amargo (mesquite) flux, Arizona, USA \\
\hline DBVPG 7110, UCD 76-12 & Prosopis juliflora Amargo (mesquite) flux, Arizona, USA \\
\hline DBVPG 7111, UCD 76-13 & Prosopis juliflora Amargo (mesquite) flux, Arizona, USA \\
\hline DBVPG 7112, UCD 76-14 & $\begin{array}{l}\text { Drosophila carbonaria Patterson and Wheeler near Prosopis juliflora } \\
\text { Amargo (mesquite) flux, Arizona, USA }\end{array}$ \\
\hline DBVPG 7113, UCD 76-15 & $\begin{array}{l}\text { Drosophila carbonaria } \text { Patterson and Wheeler near Prosopis juliflora } \\
\text { (mesquite) flux, Arizona, USA }\end{array}$ \\
\hline DBVPG 7114, UCD 76-16 & $\begin{array}{l}\text { Drosophila carbonaria Patterson and Wheeler near Prosopis juliflora } \\
\text { (mesquite) flux, Arizona, USA }\end{array}$ \\
\hline \multicolumn{2}{|c|}{ Debaryomyces hansenii (Zopf) Lodder \& Kreger-van Rij var. fabryi (Ota) Nakase \& Suzuki } \\
\hline DBVPG 6404, UCD 75-17 & (Debaryomyces subglobosus Zach ${ }^{\mathrm{T}}$ ) Diseased nail \\
\hline DBVPG $7031^{\mathrm{T}}$, UCD $96-1^{\mathrm{T}}$ & Interdigital mycotic lesion, Germany \\
\hline DBVPG 7033, IFO 0037 & (Debaryomyces fukuyamaensis Naganishi ${ }^{\mathrm{T}}$ ) Rice-vinegar mash, Japan \\
\hline DBVPG 7034, JCM 1441 & (Pichia adzetii Jacob ${ }^{\mathrm{T}}$ ) Tanning fluid, France \\
\hline DBVPG 7035, JCM 2166 & $\begin{array}{l}\text { (Blastodendrion flareri Redaelli \& } \text { Ciferri }^{\mathrm{T}} \text { ) Erythematous-squamatic skin } \\
\text { lesion, Italy }\end{array}$ \\
\hline \multicolumn{2}{|c|}{ Debaryomyces hansenii (Zopf) Lodder \& Kreger-van Rij var. hansenii } \\
\hline DBVPG 6017, CBS 1795 & Wound on hand \\
\hline DBVPG $6050^{\mathrm{T}}$, UCD $74-86^{\mathrm{T}}$ & Carlsberg laboratory \\
\hline DBVPG 6405 , UCD 72-47 & (Debaryomyces tyrocola Giovannozzi ${ }^{\mathrm{T}}$ ) Cheese \\
\hline DBVPG 6406, CBS 796 & (Debaryomyces mucosus Hufschmitt et al. ${ }^{\mathrm{T}}$ ) Skin lesion \\
\hline \multicolumn{2}{|l|}{ Debaryomyces nepalensis } \\
\hline DBVPG $7123^{\mathrm{T}}$, UCD $72-46^{\mathrm{T}}$ & Soil, Nepal \\
\hline
\end{tabular}

* CBS, Centraalbureau voor Schimmelcultures, Delft, The Netherlands; DBVPG, Collezione dei Lieviti Industriali (Industrial Yeast Collection), Sez. di Microbiologia, Dip. di Biologia Vegetale, Università di Perugia, Italy; IFO, Institute for Fermentation, Osaka, Japan; JCM, Japan Collection of Microorganisms, RIKEN, Japan; UCD, The H. J. Phaff Collection of Yeast and Yeast-like Organisms, University of California, Davis, CA, USA. T, Type strain of the species or variety.

Preparation and analyses of nuclear DNA. High-molecularmass nuclear DNA for optical reassociation experiments was obtained from $2448 \mathrm{~h}$ cultures grown in YEPG at $25^{\circ} \mathrm{C}$. Cells were suspended in a sucrose buffer $[0 \cdot 02 \mathrm{M}$ Tris, $0.02 \mathrm{M}$ EDTA, $15 \%(\mathrm{w} / \mathrm{v})$ sucrose] together with an equal volume of $0.45-0.50 \mathrm{~mm}$ diameter glass beads and were disrupted mechanically using a Bead-Beater Cell Disrupter (Biospec Products). DNA was purified according to Bernardi et al. (1970) with modifications by Price et al. (1978). DNAs to be labelled with ${ }^{125}$ I were further purified by banding in a caesium chloride gradient (Holzschu et al., 1979).

DNA base compositions were determined by buoyant density using the techniques described by Price et al. (1978). Final results were calculated from duplicate or triplicate examinations.

Nucleotide sequence homology was determined using two different techniques. Some DNA-DNA reassociation experiments were performed according to the optical method of Kurtzman et al. (1980) using a Gilford 250 spectrophotometer equipped with a model 2527 Gilford thermoprogrammer. Other studies were done using the technique of Holzschu et al. (1979) where DNA of strain DBVPG 7010 (UCD 84-100) was labelled in vitro with ${ }^{125}$ I. Sequence complementarity was determined by renaturation in $0.28 \mathrm{M}$ phosphate buffer (an equimolar mixture of monobasic and dibasic sodium phosphate, pH 6.8) at $25^{\circ} \mathrm{C}$ below the $T_{m}$ of native homologous DNA as described by Price et al. (1978). Reannealed DNA was separated from unreacted DNA by a hydroxylapatite (HA) procedure which separated singlefrom double-stranded molecules. Samples were counted in a Nuclear-Chicago model 1185 gamma counter where counting efficiency was $84 \%$.

Intact chromosomal DNA for PFGE was prepared as previously reported (Vaughan-Martini et al., 1993). All analyses were performed on a Chef Mapper (Bio-Rad) using gels composed of $1 \%$ agarose (Type II-A, medium EEO; Sigma) in $0.5 \times$ TBE buffer. Temperatures of $12-15^{\circ} \mathrm{C}$ were 
maintained throughout the runs. The run time was $68 \mathrm{~h}$ with a ramp of $1 \rightarrow 5 \mathrm{~min}$ at $4.5 \mathrm{~V} \mathrm{~cm}^{-1}$ with an angle of $120^{\circ}$.

\section{RESULTS AND DISCUSSION}

The 33 isolates from mesquite tree fluxes and Drosophila carbonaria in the Rincon and Catalina Mountains around Tucson, southern Arizona, USA (Ganter et al., 1986) were originally identified as Debaryomyces hansenii based on their physiological characteristics and the determinative key of Kreger-van Rij (1984). In the present study nine representative strains from mesquite and associated Drosphila were investigated, using an expanded array of phenotypic criteria supplemented by DNA base composition determinations, DNA-DNA hybridization and electrophoretic karyotyping experiments. Currently two varieties are recognized, Debaryomyces hansenii var. hansenii and $D$. hansenii var. fabryi (Nakase \& Suzuki, 1985a, b; Nakase et al., 1998). Nakase \& Suzuki (1985a) could not find any phenotypic criteria to distinguish the two varieties except by DNA hybridization, although in their accompanying paper (Nakase \& Suzuki, 1985b) they stated that the maximum temperature for growth of the variety hansenii was $31-35^{\circ} \mathrm{C}$ and that of the variety fabryi was $36-39^{\circ} \mathrm{C}$.

The $\mathrm{G}+\mathrm{C}$ contents of four of the mesquite strains agreed fairly closely with those reported for the two varieties of $D$. hansenii (Price et al., 1978; Nakase \& Suzuki, 1985a). However, DNA reassociation experiments, using both optical reassociation (Table 2) and labelled DNA techniques (Table 3), clearly showed that, with only approximately $30 \%$ DNA relatedness, $D$. prosopidis is a different species from $D$. hansenii var. hansenii. The relationship between $D$. prosopidis and $D$. hansenii var. fabryi appears to be closer as shown by a DNA relatedness value of $54 \%$ between the type
Table 3. Percentage DNA-DNA relatedness between ${ }^{125}$ labelled samples of Debaryomyces prosopidis DBVPG $7010^{\top}$ and other strains of Debaryomyces

\begin{tabular}{|lc|}
\hline Sample* $^{*}$ & $\begin{array}{c}\text { Hybridization } \\
(\mathbf{\%})\end{array}$ \\
\hline $\begin{array}{l}\text { D. prosopidis } \\
7010^{\mathrm{T}}\end{array}$ & $(100)$ \\
7011 & $99 \cdot 4$ \\
7012 & $97 \cdot 6$ \\
D. hansenii var. fabryi 6404 & $48 \cdot 4$ \\
D. hansenii var. hansenii & \\
$6050^{\mathrm{T}}$ & $32 \cdot 5$ \\
6405 & $29 \cdot 8$ \\
D. coudertii $7124^{\mathrm{T}}$ & $19 \cdot 4$ \\
Calf thymus DNA & $13 \cdot 5$ \\
D. nepalensis $7123^{\mathrm{T}}$ & $13 \cdot 3$ \\
D. castellii $7068^{\mathrm{T}}$ & $9 \cdot 5$ \\
\hline
\end{tabular}

*DBVPG strain nos are given - see Table 1 for other designations.

strains of these two organisms (Table 2). Although this degree of kinship is significant, it is not high enough to consider the two taxa conspecific. The same could be said about the relatedness between the two varieties of $D$. hansenii, which is also in the range of $36-54 \%$ [see Price et al. (1978) and Table 2].The reason that $D$. hansenii var. fabryi has remained a variety is that so far there are no traditional phenotypic characteristics to distinguish the two varieties (Nakase \& Suzuki, 1985a). In contrast, $D$. prosopidis can be differentiated from both varieties of $D$. hansenii by its inability to utilize cellobiose and salicin in Yeast Nitrogen Base after 2 weeks incubation. Nakase \& Suzuki (1985a) tested

Table 2. Optical DNA-DNA reassociation within Debaryomyces hansenii and related taxa

\begin{tabular}{|lccccccc|}
\hline Species* $^{*}$ & $\mathbf{6 0 1 7}$ & $\mathbf{6 0 5 0}^{\mathbf{T}}$ & $\mathbf{6 4 0 5}$ & $\mathbf{6 4 0 6}$ & $\mathbf{6 4 0 4}$ & $\mathbf{7 0 3 1}^{\mathbf{T}}$ & $\mathbf{7 0 1 0}^{\mathbf{T}}$ \\
\hline $\begin{array}{l}\text { D. hansenii var. hansenii } \\
6017\end{array}$ & $(100)$ & - & - & - & - & - & - \\
$6050^{\mathrm{T}}$ & 82 & $(100)$ & - & - & - & - & - \\
6405 & - & 75 & $(100)$ & - & - & - & - \\
6406 & 57 & 80 & 58 & $(100)$ & - & - & - \\
D. hansenii var. fabryi & & & & & & & \\
6404 & 57 & 54 & 31 & 61 & $(100)$ & - & - \\
$7031^{\mathrm{T}}$ & - & 36 & - & - & 79 & $(100)$ & - \\
7033 & - & - & - & - & - & 96 & 67 \\
7034 & - & - & - & - & - & 96 & 62 \\
7035 & - & - & - & - & 98 & 75 & - \\
D. prosopidis & & & & & & & \\
$7010^{\mathrm{T}}$ & 26 & - & 30 & - & 47 & 54 & $(100)$ \\
7011 & - & - & - & 46 & - & - & 95 \\
7012 & - & 45 & - & - & 60 & - & 99 \\
\hline
\end{tabular}

* DBVPG strain nos are given - see Table 1 for other designations. 


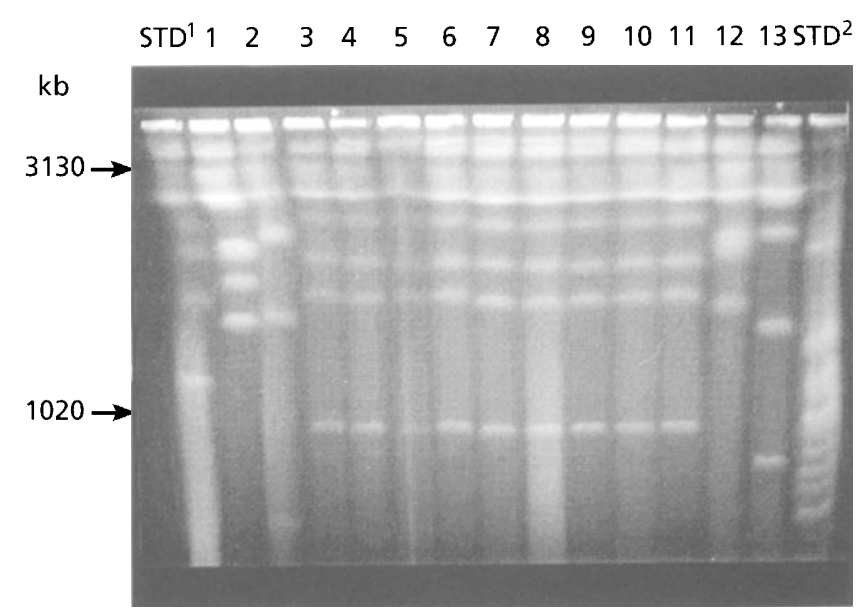

Fig. 1. Electrophoretic karyotypes of $D$. prosopidis and related strains (DBVPG strain nos given-see Table 1 for other designations). D. hansenii var. fabryi 7033 (lane 1) and $7031^{\top}$ (lane 2); D. prosopidis 7012 (lane 3), 7011 (lane 4), 7010 (lane 5), 7114 (lane 6), 7113 (lane 7), 7112 (lane 8), 7111 (lane 9), 7110 (lane 10) and 7109 (lane 11); D. hansenii var. hansenii 6406 (lane 12) and $6050^{\top}$ (lane 13). STD1, standard DNA of Pichia canadensis (syn. Hansenula wingei) and STD2, standard DNA of Saccharomyces cerevisiae (both from Bio-Rad).
34 strains of $D$. hansenii var. hansenii and six strains of $D$. hansenii var. fabryi which all grew on cellobiose and $\beta$-methyl-D-glucoside. Most strains of $D$. prosopidis including the type grew at $37^{\circ} \mathrm{C}$, except strains UCD 76-13, 76-14 and 76-15, which grew at $35-36^{\circ} \mathrm{C}$, thus enabling further discrimination between $D$. prosopidis and $D$. hansenii var. hansenii.

Also supporting the establishment of the new species, $D$. prosopidis, is the fact that the electrophoretic karyotypes of all strains of the new species are identical (Fig. 1) and significantly different from the type strain and other strains of the two varieties of $D$. hansenii. Selected diagnostic characteristics of Debaryomyces species are given in Table 4.

\section{Latin diagnosis of Debaryomyces prosopidis sp. nov.}

In medio liquido cum glucoso, peptono et extracto levedinis (post dies 3 ad $25^{\circ} \mathrm{C}$ ) cellulae ovoideae, $3.5-5.5 \times 1.5-2.5 \mu \mathrm{m}$, singulae aut binae; sedimentum; pellicula nulla. Cultura in agaro malto (post dies 25 ad $25^{\circ} \mathrm{C}$ ) eburnea, cana-cremea, butyrosa, glabra, nitida. In agaro farinae Zea mays post dies 10 pseudomycelium nullum. Asci formantur ex transformatione cellularum vegetarum (post dies $3-5,20-25^{\circ} \mathrm{C}$ ). Ascosporae

Table 4. Selected characteristics of Debaryomyces prosopidis and related taxa

-, No growth; +, strong growth in $3 \mathrm{~d},+\mathrm{s}$, growth in $6 \mathrm{~d} ;+\mathrm{w}$, growth in $14 \mathrm{~d}$; + vw, growth in $21 \mathrm{~d} ; T_{\max }$, maximum growth temperature.

\begin{tabular}{|c|c|c|c|c|}
\hline \multirow[t]{2}{*}{ Species* } & \multicolumn{2}{|c|}{ Assimilation of: } & \multirow[t]{2}{*}{$T_{\max }\left({ }^{\circ} \mathrm{C}\right)$} & \multirow[t]{2}{*}{$\mathrm{G}+\mathrm{C}$ content $(\mathrm{mol} \%) \dagger$} \\
\hline & CEL & MEL & & \\
\hline \multicolumn{5}{|c|}{ D. prosopidis } \\
\hline $7010^{\mathrm{T}}$ & - & - & 37 & $37 \cdot 54 \pm 0 \cdot 25^{\prime \prime}$ \\
\hline 7011 & - & - & 37 & $37 \cdot 42 \pm 0 \cdot 3^{t}$ \\
\hline 7012 & - & - & 37 & $37 \cdot 51 \pm 0 \cdot 3^{a}$ \\
\hline 7109 & - & - & 37 & \\
\hline 7110 & $+v w$ & - & 37 & $37 \cdot 7 \pm 0 \cdot 4^{a}$ \\
\hline 7111 & - & - & 36 & \\
\hline 7112 & - & - & 35 & \\
\hline 7113 & $+v w$ & $+w$ & 35 & \\
\hline 7114 & $+w$ & - & 37 & \\
\hline \multicolumn{5}{|c|}{ D. hansenii var. fabryi } \\
\hline 6404 & + & $+w$ & 37 & $37 \cdot 3 \pm 0 \cdot 2^{b}$ \\
\hline $7031^{\mathrm{T}}$ & + & $+w$ & 35 & $3 \overline{6} \cdot 5^{c}$ \\
\hline 7033 & + & $+\mathrm{s}$ & 35 & $36 \cdot 8^{c}$ \\
\hline 7034 & + & $+w$ & 36 & $36 \cdot 6^{c}$ \\
\hline 7035 & + & $+s$ & 37 & $36 \cdot 8^{c}$ \\
\hline \multicolumn{5}{|c|}{ D. hansenii var. hansenii } \\
\hline 6017 & + & + & $<35$ & $37 \cdot 5^{c}$ \\
\hline $6050^{\mathrm{T}}$ & + & $+w$ & $<35$ & $36 \cdot 8^{r}$ \\
\hline 6405 & + & $+w$ & $<35$ & $37 \cdot 2^{c}$ \\
\hline 6406 & + & $+w$ & $<35$ & \\
\hline
\end{tabular}

* DBVPG strain nos are given - see Table 1 for other designations.

$\dagger a$, This study (calculated from the mean of 2-3 buoyant density determinations); $b$, Price $e t a l$. (1978) (by buoyant density); $c$, Nakase \& Suzuki (1985a) (by $T_{\mathrm{m}}$ ). 
rotundae; 1-(2) in asco. Fermentatio glucosi nullum. Glucosum, galactosum, sorbosum, maltosum, saccharosum, trchalosum (lente), raffinosum, melezitosum, amylum solubile, D-xylosum, L-arabinosum, D-ribosum (exigue), ethanolum, glycerolum, erythritolum, ribitolum, D-mannitolum, D-glucitolum, methylum $\alpha-D$ -

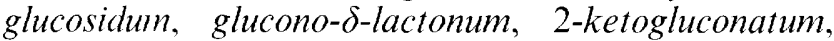
acidum succinicum, acidum citricum, acidum gluconatum, $\mathrm{N}$-acetylglucosaminum, ethyl acetas (exigue), hexadecanum assimilantur at non cellobiosum, lactosum, melibiosum, inulinum, D-arabinosum, L-rhamnosum, galactitolum, salicinum, acidum lacticum, $i$ inositolum, methanolum, glucosaminum, acetonum, 2propanolum. Lysinum, cadaverinum et ethylaminum assimilantur. Natrium nitricum et natrium nitosum non assimilantur. Ad crescentiam additae vitaminae necessariae sun . Temperatura maxima crescentiae $37^{\circ} \mathrm{C}+$, $38{ }^{\circ} \mathrm{C}-$. Crescere potest in $12.5 \% \mathrm{NaCl} / 5 \%$ glucoso, $50 \%$ glucoso, $0 \cdot 1 \mathrm{~g}$ cycloheximido $1^{-1}$. Typus depositus in collectione $\mathrm{H}$. J. Phaff Collection of Yeast and Yeast-like Organisms, UCD 84-100 $0^{\mathrm{T}}$ ) et Collezione dei Lieviti Industriali, Perusia (DBVPG 7010 $)$, CBS $8450^{\mathrm{T}}$, ATCC $201611^{\mathrm{T}}$.

\section{Description of the type strain of Debaryomyces prosopidis sp. nov.}

Debaryomyces prosopidis (pro.so'pi.dis. L. masc. gen. n. prosopidis of Prosopis, referring to the host tree of the new species).

In YM (Difco) liquid medium after $5 \mathrm{~d}$ at $25^{\circ} \mathrm{C}$, the cells are ovoid or spherical, $(3.5-5.5 \times 1.5-2.5 \mu \mathrm{m})$ and occur singly or in pairs; budding is multilateral. A sediment develops after about $10 \mathrm{~d}$; a pellicle or ring is not present. After 1 month at $20^{\circ} \mathrm{C}$, on malt agar the streak is butyrous, smooth, glistening and creamcoloured. In Dalmau plate cultures on cornmeal agar after $10 \mathrm{~d}$, no pseudohyphae or true mycelium is produced. Asci resulting from mother-daughter conjugation containing one, occasionally two, globose ascospores (diameter $3 \mu \mathrm{m}$ ) were observed after $6 \mathrm{~d}$ at $20-25^{\circ} \mathrm{C}$, on Gorodkowa agar. Fermentation is absent. Assimilates the following carbon compounds: glucose, galactose, L-sorbose, maltose, sucrose, trehalose (weakly), raffinose, melezitose, soluble starch, D-xylose. L-arabinose, D-ribose (weakly), ethanol, glycerol, ery thritol, ribitol, D-mannitol, D-glucitol, methyl $\alpha$-D-glucoside, glucono- $\delta$-lactone, 2-ketogluconate, succinate, citrate, gluconate, $\mathrm{N}$-acetyl-D-glucosamine, ethylacetate (weakly), hexadecane. Does not assimilate cellobiose, lactose, melibiose, inulin, D-arabinose, Lrhamnose, galactitol, salicin, DL-lactate, inositol, methanol, glucosamine, acetone, 2-propanol. $\mathrm{KNO}_{3}$ and $\mathrm{KNO}_{2}$ are not utilized as sole sources of nitrogen; ethylamine, cadaverine and lysine are utilized. Does not grow in vitamin-free medium. Grows weakly in presence of 100 p.p.m. cycloheximide. Grows in YM agar containing $12.5 \%(\mathrm{w} / \mathrm{w}) \mathrm{NaCl}$. Grows in the presence of $50 \%$ glucose. Does not show casein or gelatin hydrolysis; lipolytic and urease activity are lacking. Growth at $37^{\circ} \mathrm{C}+; 38^{\circ} \mathrm{C}-$. The habitat is exudate of mesquite trees (Prosopis juliflora). Cultures of the type strain have been deposited in The H. J. Phaff Collection of Yeast and Yeast-like Organisms, Department of Food Science and Technology, University of California, Davis, CA, USA, as UCD 84100 , in the Collezione dei Lieviti Industriali, Dipartimento di Biologia Vegetale, Università di Perugia, Italy (DBVPG 7010 ), in the Centraalbureau voor Schimmelcultures, Delft, The Netherlands, as CBS $8450^{\mathrm{T}}$, and the American Type Culture Collection, Rockville, MD, USA, as ATCC $201611^{\mathrm{T}}$.

\section{ACKNOWLEDGEMENTS}

We are indebted to Stefania Barcaccia for determining the electrophoretic karyotypes and for performing the optical DNA reassociation experiments; to James Haudenshield for his help with the labelled DNA reassociation experiments and to Don Vacek for his assistance in collecting the samples. This work was supported by a grant from the Italian Council for Research: Progetto coordinato CNR: Biodiversità microbica in ambienti agro-industriali. 'GERMIC' Codice 6623 to A. V.M.

\section{REFERENCES}

Bernardi, G., Faures, M., Piperno, G. \& Slonimski, P. P. (1970). Mitochondrial DNAs from respiratory-sufficient and cytoplasmic respiratory-deficient mutants of yeasts. $J \mathrm{Mol} \mathrm{Biol} \mathrm{48,}$ 23-43.

Ganter, P. F., Starmer, W. T., Lachance, M. A. \& Phaff, H. J. (1986). Yeast communities from host plants and associated Drosophila in southern Arizona: new isolations and analysis of the relative importance of hosts and vectors on community composition. Oecologia (Berlin) 70, 386-392.

Holzschu, D. L., Presley, H. L., Miranda, M. \& Phaff, H. J. (1979). Identification of Candida lusitaniae as an opportunistic yeast in humans. J Clin Microbiol 10, 202-205.

Kreger-van Rij, N. J. W. (1984). Genus Debaryomyces Lodder et Kreger-van Rij. In The Yeasts: a Taxonomic Study, 3rd edn, pp. 130-145. Edited by N. J. W. Kreger-van Rij. Amsterdam: Elsevier.

Kurtzman, C. P., Smiley, M. J., Johnson, C. J., Wickerham, L. J. \& Fuson, G. B. (1980). Two new and closely related heterothallic species, Pichia amylophila and Pichia mississippiensis: characterization by hybridization and deoxyribonucleic acid reassociation. Int $J$ Syst Bacteriol 30, 208-216.

Nakase, T. \& Suzuki, M. (1985a). Taxonomic studies on Debaryomyces hansenii (Zopf) Lodder et Kreger-van Rij and related species. I. Chemotaxonomic investigations. J Gen Appl Microbiol 31, 49-69.

Nakase, T. \& Suzuki, M. (1985b). Taxonomic studies on Debaryomyces hansenii (Zopf) Lodder et Kreger-van Rij and related species. II. Practical discrimination and nomenclature. $J$ Gen Appl Microbiol 31, 71-86.

Nakase, T., Suzuki, M. \& Phaff, H. J. (1998). Genus Debaryomyces Lodder et Kreger-van Rij. In The Yeasts: a Taxonomic Study, 4th edn, pp. 157-173. Edited by C. P. Kurtzman \& J. W. Fell. Amsterdam: Elsevier.

Phaff, H. J. \& Starmer, W. T. (1987). Yeasts associated with plants, insects, and soil. In The Yeasts, 2nd edn, vol. 1, pp. 253-296. Edited by A. H. Rose \& J. S. Harrison. London: Academic Press. 
Phaff, H. J., Blue, J., Hagler, A. N. \& Kurtzman, C. P. (1997). Dipodascus starmeri sp. nov., a new species of yeast occurring in cactus necroses. Int J Syst Bacteriol 47, 307-312.

Price, C. W., Fuson, G. B. \& Phaff, H. J. (1978). Genome comparison in yeast systematics: delimitation of species within the genera Schwanniomyces, Saccharomyces, Debaryomyces and Pichia. Microbiol Rev 42, 161-193.

Starmer, W. T., Lachance, M. A., Phaff, H. J. \& Heed, W. B. (1990).

The biogeography of yeasts associated with decaying cactus tissue in North America, the Caribbean, and Northern Venezuela. Evol Biol 24, 253-296.

Vaughan-Martini, A., Martini, A. \& Cardinali, G. (1993). Electrophoretic karyotyping as a taxonomic tool in the genus $S a c$ charomyces. Antonie Leeuwenhoek 63, 145-156.

van der Walt, J. P. \& Yarrow, D. (1984). Methods for the isolation, maintenance classification and identification of yeasts. In The Yeasts: a Taxonomic Study, 3rd edn, pp. 45-104. Edited by N. J. W. Kreger-van Rij. Amsterdam: Elsevier. 